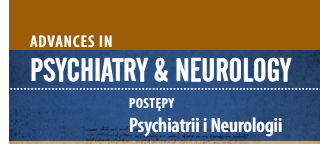

Correspondence to/

Adres do korespondencji:

Agnieszka Kruczek

Department of Clinical Psychology

Institute of Psychology

Kazimierz Wielki University

Bydgoszcz, Poland

phone: +48665221926

e-mail: agnesview@gmail.com

Submitted/Otrzymano: 18.12 .2018

Accepted/Przyjęto do druku: 21.01.2019

\section{E-HEALTH - MODERN TECHNOLOGIES IN MENTAL HEALTH CARE}

\section{E-ZDROWIE - NOWOCZESNE TECHNOLOGIE W OCHRONIE ZDROWIA PSYCHICZNEGO}

\author{
Agnieszka Kruczek \\ Department of Clinical Psychology, Institute of Psychology, Kazimierz Wielki \\ University, Bydgoszcz, Poland \\ Zakład Psychologii Klinicznej, Instytut Psychologii, Uniwersytet Kazimierza Wielkiego, \\ Bydgoszcz, Polska
}

\begin{abstract}
Purpose: The article has two main objectives: firstly, to present major issues concerning e-health, with particular emphasis on characteristics of this paradigm, patient involvement in interventions used within the e-health framework, and their effectiveness. The other aim was to discuss the e-health paradigm aspects important in diagnostics and treatment of the mentally ill.

Views: As reported in the literature, e-health paradigm solutions turned out to be highly effective in prevention, diagnosis and treatment of not only somatic conditions including cardiovascular diseases, sickle cell anemia, psoriasis, inflammatory bowel disease, interstitial cystitis, hearing impairment and osteoporosis, but also mental disorders such as substance dependence, depression, bipolar affective disorder, anxiety, distress, mental suffering, suicidal thoughts, or obsessive-compulsive behaviors. E-interventions were also used to prepare patients for surgery and to support their postoperative recovery.

Conclusions: Recognition of diverse applications of e-health tools can help design psychological interventions targeting vulnerable patient populations. This approach allows reducing costs and improving effectiveness of psychotherapy via e.g. increasing treatment intensity using digital technologies, or helping patients to integrate therapeutic strategies in their daily life between sessions. The benefits of e-health technologies implementation include increased patient participation in healthcare decision making. However, there are some limitations: financial, language and literacy barriers, power supply issues, data security and privacy issues.
\end{abstract}

Key words: mental health, mental disorders, modern technologies, e-health.

\title{
Streszczenie
}

Cel: Prezentowany artykuł ma dwojaki cel. Po pierwsze przedstawione zostaną istotne zagadnienia związane z e-zdrowiem. W szczególności skoncentrowano się na charakterystyce tego paradygmatu, poruszeniu kwestii zaangażowania pacjenta w oddziaływania w ramach e-zdrowia oraz skuteczności tych oddziaływań. Drugim celem było przedstawienie istotnych aspektów paradygmatu e-zdrowia w diagnozowaniu i leczeniu pacjentów chorych psychicznie.

Poglądy: W świetle literatury przedmiotu rozwiązania w paradygmacie e-zdrowia okazały się wysoce skuteczne w profilaktyce, diagnostyce i leczeniu pacjentów z chorobami zarówno somatycznymi: sercowo-naczyniowymi, anemią sierpowatą, łuszczycą, zapaleniem jelita, śródmiąższowym zapaleniem pęcherza moczowego, uszkodzeniami słuchu oraz osteoporozą, jak i psychicznymi: uzależnieniami substancjonalnymi, depresją, chorobą afektywną dwubiegunową, lękiem, stresem, cierpieniem psychicznym, myślami samobójczymi, zachowaniami obsesyjno-kompulsywnymi. Stosowano je także w celu przygotowania pacjentów do zabiegów chirurgicznych oraz wspierania ich zdrowienia po tych zabiegach.

Wnioski: Odkrycie różnorodności zastosowań narzędzi w ramach e-zdrowia może pomóc w zaprojektowaniu interwencji psychologicznych ukierunkowanych na wrażliwą populację pacjentów. Takie podejście pozwala na obniżenie kosztów psychoterapii lub też zwiększenie jej skuteczności, np. poprzez zwiększenie intensywności leczenia przy wykorzystywaniu technologii cyfrowych lub pomoc pacjentom $w$ integracji strategii terapeutycznych w codziennym życiu pomiędzy sesjami. Korzyści z technologii wdrażanych w ramach e-zdrowia obejmują zwiększenie udziału pacjentów w decyzjach terapeutycznych. Mają one jednak pewne ograniczenia: bariery finansowe, językowe i związane z umiejętnością czytania i pisania, kwestie związane z zasilaniem, bezpieczeństwem danych i prywatnością.

Słowa kluczowe: zdrowie psychiczne, zaburzenia psychiczne, nowoczesne technologie, e-zdrowie. 


\section{INTRODUCTION}

Mobile technologies change the ways of human communication, provide a broad access to resources, enable easy information finding, and support healthcare initiatives all over the world [1]. Due to the development of such technologies self-management strategies can be used in daily life, including health-related behaviors [2]. The rapid expansion of online medical resources may be regarded as revolutionary, as they change the patient's role in the diagnosis and treatment processes from that of a passive recipient to a partner [3-5]. Enthusiasm for e-health technologies worldwide may result also from their potential to transform healthcare and improve its quality [5-9].

Relevant literature suggests that e-health solutions turned out to be highly successful in the prevention, diagnostics and treatment of not only somatic conditions such as cardiovascular diseases $[10,11]$, sickle cell anemia [12], psoriasis [13], inflammatory bowel disease [14], interstitial cystitis [15], hearing impairment $[16,17]$ and osteoporosis [18], but also mental disorders [11] including substance dependence $[19,20]$, depression $[21,22]$, bipolar affective disorder [23], anxiety, distress, mental suffering, suicidal thoughts, or obsessive-compulsive behaviors [24-29]. E-interventions were also used to prepare patients for surgery and to support their postoperative recovery [30-34].

Considering medical and psychological research findings reported so far as well as experiences from e-health solutions implementation in psychological assistance provision to various patient groups, a twofold goal was set in the present paper. Firstly, major issues concerning e-health will be discussed, with particular emphasis on features of this paradigm, the problem of patient involvement in e-health interventions, and their effectiveness. Secondly, e-health aspects important for the diagnosis and treatment of mental illness will be outlined.

\section{CHARACTERISTICS OF E-HEALTH PARADIGM}

In the present paper e-health is understood in line with the World Health Organization (WHO) definitions [35]. Initially in the WHO e-Health Resolution of 2005 the construct was described in broad terms as the application of information and communication technologies (ICT) to support both regional and interregional initiatives in the sphere of health and healthrelated domains, including healthcare services, supervision, and health promotion [35]. In the subsequent

\section{WPROWADZENIE}

Technologie mobilne zmieniają sposób, w jaki jednostki komunikują się ze sobą, umożliwiają szeroki dostęp do zasobów, wyszukiwanie informacji i wspieranie inicjatyw związanych z opieką zdrowotną na całym świecie [1]. Rozwój technologii daje możliwość samodzielnego zarządzania własnym zachowaniem w codziennym życiu jednostki, w tym zachowaniami zdrowotnymi [2]. Szybka ekspansja cyfrowych zasobów medycznych online może być postrzegana jako rewolucyjna, zmieniająca rolę pacjenta $\mathrm{w}$ procesie diagnozy i leczenia $\mathrm{z}$ biernego odbiorcy na partnera [3-5]. Entuzjazm dla elektronicznych technologii w służbie zdrowiu (e-zdrowie; e-health) na świecie można także wiązać $\mathrm{z}$ jego potencjałem do przetransformowania opieki zdrowotnej i poprawy jej jakości [5-9].

W świetle literatury przedmiotu rozwiązania stosowane w paradygmacie e-zdrowia okazały się bardzo skuteczne w profilaktyce, diagnostyce i leczeniu pacjentów z chorobami zarówno somatycznymi: sercowo-naczyniowymi $[10,11]$, anemią sierpowatą [12], łuszczycą [13], zapaleniem jelita [14], śródmiąższowym zapaleniem pęcherza moczowego [15], uszkodzeniami słuchu $[16,17]$ oraz osteoporozą [18], jak i psychicznymi [11]: uzależnieniami od substancji psychoaktywnych $[19,20]$, depresją $[21,22]$, chorobą afektywną dwubiegunową [23], lękiem, stresem, cierpieniem psychicznym, myślami samobójczymi, zachowaniami obsesyjno-kompulsywnymi [24-29]. Stosowano je także w celu przygotowania pacjentów do zabiegów chirurgicznych oraz wspierania ich zdrowienia po tych zabiegach [30-34].

W kontekście wyników badań, które dotychczas zostały przeprowadzone na gruncie medycyny i psychologii i doświadczeń związanych $\mathrm{z}$ wdrażaniem rozwiązań e-zdrowia $\mathrm{w}$ pomocy psychologicznej w różnych grupach chorych, prezentowany artykuł ma dwojaki cel. Po pierwsze przedstawione zostaną istotne zagadnienia związane $\mathrm{z}$ e-zdrowiem. W szczególności skoncentrowano się na charakterystyce tego paradygmatu, poruszeniu kwestii zaangażowania pacjenta w oddziaływania w ramach e-zdrowia oraz skuteczności tych oddziaływań. Drugim celem było przedstawienie istotnych aspektów paradygmatu e-zdrowia w diagnozie i leczeniu pacjentów chorych psychicznie.

\section{CHARAKTERYSTYKA PARADYGMATU E-ZDROWIA}

W prezentowanej pracy przyjęto rozumienie e-zdrowia za Światową Organizacją Zdrowia (World Health Organization - WHO) [35]. Początkowo WHO w rezolucji w sprawie zdrowia z roku 2005 opisywała e-zdrowie (e-health) z szerokiej perspektywy jako wykorzystanie technologii informacyjnych i komunikacyjnych (informatic and communication technologies - ICT) lokalnie i na odległość w celu wspierania zdrowia i dziedzin związanych ze zdrowiem, w tym usług opieki zdrowot- 
WHO definition of 2016 new perspectives were introduced regarding e-health scope and services, namely, the use of electronic means of information provision, health-related resources and services. In this definition a number of most recent domains of the online health revolution are highlighted, such as electronic health records, health analytics, computational tools, and mobile health (m-Health).

The ways of supporting patient health using modern electronic technologies have considerably changed over the past ten or fifteen years, as regards not only the services and functions offered, but also digital platforms for these services provision. These include e.g. telehealth, services provided using DVD-video discs and personal computer (PC) applications, or phone services [15, 36]. More recently e-health interventions are provided via the Internet (web-based platforms) or mobile platforms [36], involving the use of intelligent sensors and personal biofeedback devices [37]. Such interventions may include also telemonitoring (or remote monitoring of the patient's current health status), telerehabilitation (where the patient is supported by e-health devices in the recovery process instead of receiving conventional treatment at a rehabilitation center), and e-consultations [38-41].

The advantage of e-tools used in the e-health system is their global scope. They facilitate the diagnosis, prevention and treatment of both physical and mental disorders $[4,11]$, and allow to obtain not only objective, but also subjective data concerning the patient's acute symptoms or wellbeing, their quality of life, sleep, or other physiological indicators, etc. [11]. Another indisputable advantage of e-health paradigm is the possibility of collecting information from the patients in their daily life environment over even a few weeks. This allows documenting the patient's baseline status and monitoring their psychophysical functioning over time, in response to various life events, but first and foremost, in response to the interventions provided [11].

It should be noted that the electronic healthcare system cannot be reduced to recommending a specific e-health online program to the patient and providing them with access to an appropriate platform. Patients should be motivated to work with the program. Therefore, in order to effectively support patients and to integrate online treatment applications and programs, expertise in the field of digital media and the electronic healthcare system is required from health care professionals [11]. nej, nadzoru i promocji zdrowia [35]. Kolejna definicja WHO z 2016 r. wprowadziła nowe perspektywy dotyczące zakresu i usług e-zdrowia, gdyż opisuje je jako wykorzystanie elektronicznych środków dostarczania informacji, zasoby i usługi związane ze zdrowiem. Obejmuje wiele domen, w tym m.in.: elektroniczną dokumentację medyczną (electronic health records), mobilne zdrowie (mobile health, m-Health) i analitykę zdrowotną (health analytics). Ta późniejsza definicja akcentowała najnowsze aspekty cyfrowej rewolucji zdrowia, takie jak analityka zdrowotna, narzędzia obliczeniowe i mobilne zdrowie.

W ciągu ostatnich kilkunastu lat nastąpily istotne zmiany $\mathrm{w}$ sposobie wspomagania zdrowia pacjentów przy wykorzystywaniu nowoczesnych technologii elektronicznych. Nie tylko pod względem oferowanych usług i funkcji, ale także platform do świadczenia tych usług. Można wyodrębnić tutaj: telezdrowie (telehealth), świadczenia zamieszczane na cyfrowych dyskach wideo (DVD) i aplikacjach na komputerze osobistym (PC) lub usługi telefoniczne $[15,36]$. Nowsze rozwiązania $w$ ramach e-zdrowia dostarczane są przez internet (określane jako platformy internetowe; Internet-based platforms) lub za pomocą urządzeń przenośnych (określanych jako platformy mobilne; mobile-based platforms) [36]. Należą do nich inteligentne czujniki i osobiste urządzenia do biofeedbac$\mathrm{ku}$ [37]. Interwencje w ramach e-zdrowia mogą dotyczyć również telemonitorowania (telemonitoring), gdzie stan pacjentów jest monitorowany na odległość; telerehabilitacji (telerehabilitation), w której pacjenci są wspierani przez urządzenia e-zdrowia $w$ procesie regeneracji, zamiast uczęszczania w trybie konwencjonalnym do centrum rehabilitacji, czy e-konsultacji (e-consultations) [38-41].

Zaletą narzędzi stosowanych $\mathrm{w}$ ramach e-zdrowia (e-tools) jest ich globalny zasięg. Ułatwiają diagnostykę, zapobieganie i leczenie zarówno zaburzeń somatycznych, jak i psychicznych $[4,11]$. Są one w stanie oceniać nie tylko obiektywne, ale również subiektywne informacje na temat doświadczania przez pacjenta ostrych objawów czy też dobrego samopoczucia, na temat jakości jego życia i snu lub innych wskaźników fizjologicznych itp. [11]. Niezaprzeczalnie kolejną zaletą paradygmatu e-zdrowia jest możliwość zbierania danych od pacjentów w ich środowisku życia nawet przez kilka tygodni. Daje to możliwość dokumentowania stanu wyjściowego pacjenta i monitorowania zmian jego psychofizycznego funkcjonowania $\mathrm{w}$ czasie, pod wpływem różnych wydarzeń życiowych, ale przede wszystkim w efekcie zastosowanych interwencji [11].

Należy jednak pamiętać, że elektroniczny system opieki zdrowotnej nie działa wyłącznie przez zalecenie pacjentowi korzystania $\mathrm{z}$ określonego programu lub zapewnienie dostępu do platformy online. Pacjentów należy motywować do pracy z programem. Efektywny system pracy wymaga zatem od specjalistów stania się ekspertami w dziedzinie mediów cyfrowych i elektronicznego systemu opieki zdrowotnej, aby mogli skutecznie wspierać pacjentów i integrować aplikacje i programy online w leczeniu [11]. 


\section{E-HEALTH AND CHANGE IN THE PATIENT-HEALTH CARE PROFESSIONAL RELATIONSHIP}

Despite many advantages of electronic technologies implementation in healthcare, research findings show that their effectiveness depends on thorough assessment of the patients' state and functioning, as well as on establishing and maintaining an emphatic relationship with them [42]. It is of pivotal importance that realistic goals of electronic interventions, with patients' individual barriers accounted for, should be set in a direct contact with the health care professional [42].

Relational aspects such as mutual trust and vulnerability in the patient-health care professional (HCP) relationships concerning health-related Internet information and the space of clinical encounters should be taken under consideration [3]. Thus, patient participation in e-health interventions leads to a shift in the patient role from the traditionally passive one to that of partnership both in the diagnostic process and treatment itself. The shifting role of patients results in a change in the patient-healthcare professional (HCP) relationship [3]. In the context of psychological diagnosis the patient is not perceived by HCPs any more as an individual suffering from a narrowly defined disease or as an object of clinical observation conducted within the limited space of consultation, but rather as an evolving subject whose behavior has been disturbed by inadequacy of his functioning to the situation. These functions can be characterized in real time in terms of many parameters and their mutual interactions [43-45].

\section{PATIENT RESPONSIBILITY AND INVOLVEMENT IN E-HEALTH PARADIGM}

Becoming partners of HCPs patients begin to take on more responsibility for their self-management with an appropriate support. They get more involved in the decision-making process concerning their treatment methods $[3,20]$. Online treatment programs support patient self-help initiatives through implementation of self-management techniques, calisthenics exercises to improve strength and agility, or relaxation techniques [11].

As regards patient involvement in the use of e-tools, it should be noted that an invitation to participate in a system of help materially embedded in the e-health paradigm does not necessarily result in the patient's engagement [46]. The phenomenon of patient engagement in using e-tools can be better understood owing to the findings by Karen Nielsen and Henriette Langstrup [46]. In their research enrolling patients with cardiovascular diseases [46] the authors distinguished

\section{E-ZDROWIE A ZMIANA RELACJI POMIĘDZY PACJENTEM A SPECJALISTA}

Mimo licznych zalet korzystania z elektronicznych technologii w służbie zdrowiu, wyniki badań pokazują, że ich skuteczność uzależniona jest od dokładnego poznania stanu pacjenta, jego funkcjonowania, nawiązywania i utrzymywania empatycznej relacji z nim [42]. W bezpośrednim kontakcie ze specjalistą kluczowe jest ustalenie realistycznych celów elektronicznych interwencji przy uwzględnieniu indywidualnych barier pacjentów [42].

Aspekty relacyjne, takie jak wzajemne zaufanie i wrażliwość w interakcjach pomiędzy pacjentami a specjalistami wokół internetowych informacji związanych ze zdrowiem stanowi przestrzeń spotkań klinicznych [3]. W ramach uczestnictwa $w$ oddziaływaniach e-zdrowia dochodzi zatem do zmiany roli odgrywanej przez pacjenta $-z$ tradycyjnie biernego staje się on partnerem procesu diagnostycznego i samego leczenia. Zmiana roli rzutuje na zmianę relacji pomiędzy pacjentem a pracownikiem służby zdrowia [3]. W kontekście diagnozy psychologicznej pacjent nie jest tu postrzegany przez specjalistę jako osoba dotknięta chorobą w wąskim kontekście lub jako przedmiot klinicznych obserwacji poczynionych w ograniczonej przestrzeni konsultacji. Zamiast tego pacjent zostaje ukazany jako podmiot ewolucji, w sytuacji którego zachowanie zostaje zakłócone przez nieadekwatność jego funkcji do funkcji jego sytuacji. Funkcje te można scharakteryzować w czasie rzeczywistym za pomocą wielu parametrów i we wzajemnych interakcjach tych parametrów [43-45].

\section{ODPOWIEDZIALNOŚĆ I ZAANGAŻOWANIE PACJENTÓW W PARADYGMACIE E-ZDROWIA}

Pacjenci, stając się partnerami profesjonalistów, zaczynają brać większą odpowiedzialność za zarządzanie sobą przy stosownym wsparciu. Stają się bardziej zaangażowani w procesie podejmowania decyzji o sposobie leczenia $[3,20]$. Programy leczenia online wspierają pacjenta w samopomocy poprzez wdrażanie do samodzielnego zarządzania sobą, stosowanie ćwiczeń wzmacniających i usprawniających czy technik relaksacji [11].

$\mathrm{W}$ kwestii zaangażowania $\mathrm{w}$ korzystanie $\mathrm{z}$ e-narzędzi warto wspomnieć, że samo zaproszenie pacjenta do uczestnictwa w systemie pomocy osadzonym materialnie w paradygmacie e-zdrowia nie stanowi o jego zaangażowaniu [46]. Większe rozumienie zaangażowania pacjentów w korzystanie z e-narzędzi umożliwiło dostrzeżenie przez Karen Nielsen i Henriette Langstrup [46] linii taktycznych uczestnictwa w tych oddziaływaniach. W świetle wyników badań przeprowadzonych $\mathrm{w}$ grupie pacjentów $\mathrm{z}$ chorobami układu krążenia [46] można wyodrębnić trzy typy 
three types of participatory tactics or patient engagement in e-health interventions, namely: activism, partnership, and compliance. Activists represented a pragmatic attitude towards and low expectations of the web application. Moreover, they were eager to experiment. Although willing to get actively involved in e-health interventions and to take on responsibility, they manifested personal distance to them [46]. The partnership type of involvement was associated with the patient's high expectations of the e-tool and disappointment in case of the tool failure. Patients' engagement in the web application use was proportional to possibilities of their participation in decision making pivotal to the interventions in question [46]. The third type of involvement, i.e. compliance, resulted from the patient's sense of duty. These patients' attitudes towards participation and engagement in e-health interventions were motivated by their striving for the good of others, or by willing to reduce their families' anxiety about their medical condition. They tried to minimize their engagement, and complied with interventions while expressing doubts about their participation in the intervention [46].

\section{EFFECTIVENESS OF E-TOOLS}

Efficacy of e-tools turned out to depend not only on their formal aspects (such as interactivity of web applications, their visual attractiveness, capability of medication schedule monitoring), but also on their contents - first and foremost provision of reliable health-related information. Virtual prizes for fulfillment of certain tasks were found to be of key importance - in other words, motivational and emotional aspects should be taken into account, as they constitute essential elements of support provided to patients [10].

Numerous short-term research studies indicate that the e-health system is highly effective as regards interventions targeted at patient lifestyle changes including body weight reduction [47], withdrawal from nicotine and other habit-forming substances, or increasing physical activity [42]. The research findings reported by John Naslund and collaborators [47] from their study involving people with obesity show effectiveness of mobile applications in body weight reduction. E-tools provided the study participants with motivation to change their lifestyle, helped them improve self-control and use social media. Effectiveness of e-health programs in promoting lifestyle changes and in rehabilitation depended on collaboration of professionals from various disciplines: dieticians, nurses, physiotherapists, occupational therapists, and psychologists who begin to fulfill the role of e-health coaches $[42,48]$. zaangażowania w oddziaływania w ramach e-zdrowia: typ aktywny (acivism), partnerski (partnership) i uległy (compliance). W przypadku zaangażowania aktywnego znaczenie miało podejście pragmatyczne do aplikacji i małe oczekiwania względem niej. Osoba miała ponadto zapał do eksperymentowania. Pomimo chęci aktywnego zaangażowania w oddziaływania e-zdrowia i wzięcia za siebie odpowiedzialności, prezentowała do nich osobisty dystans [46]. Typ partnerski zaangażowania związany był z posiadaniem przez jednostkę dużych oczekiwań względem e-narzędzia oraz rozczarowaniem w przypadku niepowodzeń jego działania. Zaangażowanie w udział w aplikacji było proporcjonalne do możliwości uczestnictwa w podejmowaniu decyzji kluczowych dla tych oddziaływań [46]. Ostatni typ zaangażowania - uległy - wynikał z poczucia obowiązku jednostki. Postawę względem uczestnictwa i zaangażowania w oddziaływania w ramach e-zdrowia pacjentów charakteryzowało kierowanie się dobrem innych ludzi bądź chęć zredukowania obaw rodziny o ich stan. Osoby starały się ograniczyć swoje zaangażowanie do minimum, podporządkowywały się oddziaływaniom, przy jednoczesnym wyrażaniu wątpliwości co do własnego uczestnictwa w nich [46].

\section{SKUTECZNOŚĆ NARZĘDZI W RAMACH ODDZIAŁYWAŃ E-ZDROWIA}

Skuteczność e-narzędzi uzależniona była nie tylko od ich aspektów formalnych, wyrażających się w interaktywności aplikacji, ich atrakcyjności wizualnej, możliwości monitorowania przyjmowania leków, ale także od aspektów merytorycznych - głównie dostarczania wiarygodnych informacji na temat zdrowia. Kluczową rolę odgrywały wirtualne nagrody otrzymywane po zrealizowaniu określonych zadań, czyli uwzględnianie aspektu motywacyjnego i emocjonalnego, które są ważnymi elementami w dostarczaniu wsparcia psychospołecznego pacjentom [10].

W świetle licznych badań krótkoterminowych system e-zdrowia okazał się niezwykle efektywny, jeśli chodzi o oddziaływania mające na celu zmianę stylu życia pacjentów dotyczącą utraty masy ciała [47], odstawienia nikotyny i innych substancji uzależniających czy wzrostu poziomu aktywności fizycznej [42]. Wyniki badań Johna Naslunda i wsp. [47], które zostały przeprowadzone w populacji osób otyłych, wykazały, że aplikacje mobilne były skuteczne w redukcji ich masy ciała. Sprzyjało temu dostarczanie przez e-narzędzia motywacji do zmiany stylu życia, pomocy w samokontroli czy łączności z mediami społecznościowymi. Efektywność programów e-zdrowia w promowaniu zmiany stylu życia i rehabilitacji zależała od współpracy profesjonalistów z różnych dziedzin: dietetyków, pielęgniarek, fizjoterapeutów, terapeutów zajęciowych, psychologów, którzy zaczynają odgrywać rolę trenerów e-zdrowia [42, 48]. 
Research conducted among persons with severe mental illness (SMI) has shown that to be effective, e-health applications should be designed according to certain guidelines accounting for such important variables as limitation of hierarchy of applications, page complexity, content disclosure, navigational simplicity, i.e. distinct navigation areas, etc. [49].

\section{E-HEALTH IN MENTAL HEALTH CARE}

E-health technologies are becoming integral elements of general models of medical care provision, also to people with mental health problems [49], particularly in countries where accessibility to psychiatric care is very limited due to their geographical location (e.g., United States, African countries) [50,51].

Different e-tools have been implemented in mental health care for therapeutic purposes, including interactive classes to teach self-help skills [50], computer games to practice strategies of coping with stress [51], or avatar therapy sessions [52]. Therapeutic interventions were supported by mobile phone sensors and other devices used as applications for symptom monitoring and motivating patients to health-promoting behaviors [53].

In psychiatry and clinical psychology smartphone applications are widely used, particularly in diagnosis and treatment of depression. Nasser F. BinDhim et al. [54] reported use of smartphone applications to screen for depression, while John Torous et al. [21] indicated how monitoring of individuals' mental state and mood can be additionally improved by smartphone apps. Agnes Grünerbl et al. [23] highlighted usefulness of smartphone-based technologies for monitoring mood swings in persons with bipolar affective disorder.

As noted by Rosauer E. Orengo-Aguayo et al. [55] in their study, adolescents in psychiatric care attending trauma focused cognitive behavioral therapy (TF-CBT) perceived e-technologies in healthcare as most useful and attractive. The teenagers argued that e-tools were familiar to them and might considerably improve the process of their treatment.

\section{CONCLUSIONS}

The recognition of diversity of e-technologies application in healthcare may help design psychological interventions targeting vulnerable patient populations [47]. The e-tools may be used to aid people with mental disorders and to increase their access to treatment. The approach in question allows to reduce costs of psychotherapy and/or improve its effectiveness, e.g. by using digital technologies to increase treatment intensity, or helping patients to integrate therapeutic strategies in their
Wyniki badań przeprowadzonych w grupie osób z ciężką chorobą psychiczną pokazały, że aby aplikacje stworzone w ramach e-zdrowia były skuteczne, powinny być zaprojektowane zgodnie z pewnymi wytycznymi, w tym ważne jest ograniczenie hierarchii aplikacji, stosowanie jawnego tekstu, wykorzystywanie pomocy nawigacyjnych itp. [49].

\section{E-ZDROWIE W SŁUŻBIE ZDROWIU PSYCHICZNEMU}

Aplikacje e-zdrowia stają się integralnymi elementami ogólnych modeli świadczenia opieki medycznej i pojawiają się także w ramach opieki nad zdrowiem psychicznym pacjentów [49]. Szczególnie dotyczy to krajów, gdzie dostęp do opieki psychiatrycznej jest bardzo ograniczony ze względu na ich położenie geograficzne (np. Stany Zjednoczone, kraje afrykańskie) [50, 51].

Różnorodne narzędzia wdrażane w ramach e-zdrowia psychicznego były wykorzystywane $\mathrm{w}$ celach terapeutycznych. Przeprowadzano interaktywne lekcje mające na celu naukę samopomocy [50]. Wykorzystywano gry komputerowe, za pomocą których ćwiczone były strategie radzenia sobie ze stresem [51]. Prowadzono sesje terapeutyczne za pomocą awatara [52]. Wsparciem dla terapii były czujniki telefonu i inne urządzenia, które wykorzystywano jako aplikacje służące monitorowaniu objawów i motywowaniu do zachowań prozdrowotnych [53].

W psychiatrii i psychologii klinicznej szeroko stosowane są aplikacje na smartfony, szczególnie w przypadku diagnozy i leczenia depresji. Nasser F. BinDhim i wsp. [54] opisywali, że za pomocą aplikacji na smartfony można przeprowadzić badania przesiewowe depresji. Z kolei John Torous i wsp. [21] wskazywali, w jaki sposób aplikacje na smartfony mogą być wykorzystywane jako dodatek do pomocy w monitorowaniu stanu psychicznego jednostek i ich nastroju. Agnes Grünerbl i wsp. [23] podkreślali, że technologie bazujące na smartfonach mogą być wykorzystywane także do monitorowania zmian nastroju u osób, które cierpiały na zaburzenie afektywne dwubiegunowe.

W świetle wyników badań Rosauera E. Orengo-Aguayo i wsp. [55], przeprowadzonych wśród adolescentów leczących się psychiatrycznie, uczestniczących w terapii poznawczo-behawioralnej ukierunkowanej na poradzenie sobie $\mathrm{z}$ traumą (TF-CBT), nastolatkowie postrzegali elektroniczne technologie w służbie zdrowiu jako niezwykle użyteczne i atrakcyjne. Argumentowali, że e-narzędzia są im znajome i mogłyby one znacznie usprawnić proces ich leczenia.

\section{WNIOSKI}

Odkrycie różnorodności zastosowań narzędzi w ramach e-zdrowia może pomóc w zaprojektowaniu interwencji psychologicznych ukierunkowanych na wrażliwą populację pacjentów [47]. Technologie te mogą być przy- 
daily life between sessions [20,54]. A common element of such interventions consists in the fact that emotional, cognitive and behavioral processes are modified in psychotherapy, whereas generalization of the modifications on the patients' daily life is promoted by the use of e-technology recommended by the psychotherapist [51].

Benefits of technologies implemented within the e-health approach include increased patient involvement in therapeutic decision-making [15], and reduced number of hospitalizations [55]. Moreover, psychiatric treatment in this paradigm may reduce the stigma of mental illness and allow for personalized pace of treatment progress [56].

Potential barriers and limitations in e-mental health should be noted, including financial, language, and literacy barriers, power supply issues, as well as data safety and privacy $[1,20]$. Moreover, numerous pilot studies testing e-tools effectiveness indicate that available infrastructure and equipment are inappropriate, human resources and skills insufficient, funding for this paradigm development limited, and legislation inadequate [57].

The effects of modern technologies are limited also due to an insufficient availability to and use of computers, smartphones, Internet and e-mails [58] by the mentally ill, in particular. According to Ben-Zeev et al. [58], only $72 \%$ of people with severe mental illness had a mobile phone. In other studies some patients with schizophrenia turned out to be unfamiliar with mobile phones [59]. Additionally, negative symptoms [59] and cognitive impairments [60] in schizophrenia may constitute a further potential barrier to using e-tools.

Finally, ethical aspects of interventions in the e-health paradigm seem to deserve attention. The fact that technological solutions for supporting mental health (mostly smartphone applications) have had no scientific rationale so far [61], seems to raise ethical questions. Thus, it could happen that because of e-tools' limited usefulness and lack of validity these applications could not be integrated into their users' daily routines [62]. datnym narzędziem służącym do pomocy osobom z zaburzeniami psychicznymi i zwiększenia im dostępu do leczenia. Takie podejście pozwala na obniżenie kosztów psychoterapii lub też zwiększenie jej skuteczności, np. poprzez zwiększenie intensywności leczenia przy wykorzystywaniu technologii cyfrowych lub pomoc pacjentom w integracji strategii terapeutycznych w codziennym życiu pomiędzy sesjami $[20,54]$. Wspólny element takich interwencji polega na tym, że emocjonalne, poznawcze i behawioralne procesy są modyfikowane w psychoterapii. Natomiast uogólnienie ich na codzienne życie użytkowników jest promowane przy użyciu ustalonej przez psychoterapeutę e-techniki [51].

Korzyści z technologii wdrażanych w ramach e-zdrowia obejmują zwiększenie udziału pacjentów w decyzjach terapeutycznych [15], zmniejszenie liczby pacjentów hospitalizowanych [55]. Ponadto leczenie psychiatryczne $\mathrm{w}$ tym paradygmacie może zmniejszać stygmatyzację pacjentów i pozwolić na zindywidualizowane tempo postępów leczenia [56].

Należy zwrócić uwagę na potencjalne bariery i ograniczenia e-zdrowia psychicznego, $w$ tym bariery finansowe, językowe i związane z umiejętnością czytania i pisania, kwestie związane z zasilaniem, bezpieczeństwem danych i prywatnością $[1,20]$. Oprócz tego liczne pilotaże sprawdzające efektywność narzędzi w ramach e-zdrowia pokazały, że dostępna infrastruktura i sprzęt są nieodpowiednie, zasoby ludzkie i umiejętności niewystarczające, fundusze na rozwój tego paradygmatu ograniczone, a ustawodawstwo nieadekwatne [57].

Wpływ nowoczesnych technologii jest ograniczony także przez dostęp i korzystanie z komputerów, smartfonów, internetu i e-maili [58], szczególnie przez osoby chore psychicznie. W świetle wyników badań Ben-Zeev i wsp. [58] $72 \%$ osób z poważnymi chorobami psychicznymi miało telefon komórkowy. Inne badania wykazały, że część osób ze schizofrenią nie znała telefonów komórkowych w ogóle [59]. Dodatkowo objawy negatywne [59] i pogorszenie sprawności funkcji poznawczych [60] w schizofrenii mogą stanowić potencjalną barierę dla korzystania z e-narzędzi.

Należy pamiętać także o etycznym aspekcie oddziaływań w paradygmacie e-zdrowia. Wątpliwości natury etycznej wzbudza to, że dotychczasowe rozwiązania technologiczne dla wspierania zdrowia psychicznego (głównie aplikacje na smartfony) nie miały podstaw naukowych [61]. Zdarzało się, że użytkownicy tych narzędzi nie mogli zatem włączyć aplikacji do rutyny dnia codziennego z powodu ich małej użyteczności i braku trafności [62]. 


\section{Conflict of interest/Konflikt interesu}

Absent./Nie występuje.

\section{Financial support/Finansowanie}

Absent./Nie występuje.

\section{References/Piśmiennictwo}

1. Brian RM, Ben-Zeev D. Mobile health (mHealth) for mental health in Asia: objectives, strategies, and limitations. Asian J Psychiatr 2014; 10: 96-100.

2. Tang C, Lorenzi N, Harle CA, Zhou X, Chen Y. Interactive systems for patient-centered care to enhance patient engagement. J Am Med Inform Assoc 2016; 23: 2-4.

3. Townsend A, Leese J, Adam P, McDonald M, Li L, Kerr S, Backman C. eHealth, Participatory Medicine, and Ethical Care: A Focus Group Study of Patients' and Health Care Providers' Use of Health-Related Internet Information. J Med Internet Res 2015; 17: e155.

4. Istepanian RSH, Al-Anzi T. m-Health 2.0: New perspectives on mobile health, machine learning and big data analytics. Methods 2018; 8: 12-20.

5. Sadegh SS, Khakshour SP, Sepehri MM, Assadi V. A framework for m-health service development and success evaluation. International Journal of Medical Informatics 2018; 112: 123-130.

6. World Health Organization [WHO], International Telecommunications Union [ITU]. National eHealth strategy toolkit. Geneva: WHO; 2012.

7. Duplaga M. The acceptance of e-health solutions among patients with chronic respiratory conditions. Telemed J E Health 2013; 19: 683-691.

8. Fairbrother P, Ure J, Hanley J, McCloughan L, Denvir M, Sheikh A, et al. Telemonitoring for chronic heart failure: the views of patients and healthcare professionals - a qualitative study. J Clin Nurs 2014; 23: 132-144.

9. Kautsch M, Lichon M, Matuszak N. Setting the scene for the future: implications of key legal regulations for the development of e-health interoperability in the EU. Int J Health Plann Manage 2017; 32: 637-652.

10. Neubeck L, Peiris D, Mulley J, Heeley E, Hersch F, Redfern J. Development of an integrated e-health tool for people with, or at high risk of, cardiovascular disease: The Consumer Navigation of Electronic Cardiovascular Tools (CONNECT) web application. Int J Med Inform 2016; 96: 24-37.

11. Lüttke S, Hautzinger M, Fuhr K. E-Health in Diagnostik und Therapie psychischer Störungen: Werden Therapeuten bald überflüssig? [E-health in diagnosis and therapy of mental disorders: Will therapists soon become superfluous?]. Bundesgesundheitsblatt Gesundheitsforschung Gesundheitsschutz 2018; 61: 263-270.

12. Badawy SM, Cronin RM, Hankins J, Crosby L, DeBaun M, Thompson AA, et al. A Patient-Centered eHealth Interventions for Children, Adolescents, and Adults With Sickle Cell Disease: Systematic Review. J Med Internet Res 2018; 20: 5-17.

13. Svendsen MT, Andersen F, Andersen KE. eHealth Technologies as an intervention to improve adherence to topical antipsoriatics: a systematic review. J Dermatolog Treat 2018; 29: 123-128.

14. Walsh A, Travis S. What's app? Electronic health technology in inflammatory bowel disease. Intest Res 2018; 16 : 366-373.

15. Lee MH, Wu HC, Tseng CM, Ko TL, Weng TJ, Chen YF. Health education and symptom flare management using a video-based m-Health system for caring women with IC/BPS. Urology 2018; 119: 62-69.

16. Ferguson M, Brandreth $M$, Brassington $W$, Leighton $P$, Wharrad $H$. A randomized controlled trial to evaluate the benefits of a multimedia educational program for first-time hearing aid users. Ear Hear 2016; 37: 123-136.

17. Penteado SP, de Lima Ramos S, Battistella LR, Marone SAM, Bento RF. Remote hearing aid fitting: tele-audiology in the context of Brazilian public policy. Int Arch Otorhinolaryngol 2012; 16: 371-381.

18. Ryan P, Papanek P, Csuka ME, Brown ME, Hopkins S, Lynch S, et al. Background and method of the Striving to be Strong study a RCT testing the efficacy of a m-health self-management intervention. Contemporary Clinical Trials 2018; 71: 80-87.

19. Woolderink M, Smit F, van der Zanden R, Beecham J, Knapp M, Paulus A, Evers S. Design of an internet-based health economic evaluation of a preventive group-intervention for children of parents with mental illness or substance use disorders. BMC Public Health 2010; 10: 470.

20. Donker T, Petrie K, Proudfoot J, Clarke J, Birch MR, Christensen H. Smartphone for the smarter delivery of mental health programs: a systematic review. J Med Internet Res 2013; 15: e247.

21. Torous J, Friedman R, Keshavan M. Smartphone ownership and interest in mobile applications to monitor symptoms of mental health conditions. JMIR Mhealth Uhealth 2014; 2: e2.

22. BinDhim NF, Shaman AM, Trevena L, Basyouni MH, Pont LG, Alhawassi TM. Depression screening via a smartphone app: cross-country user characteristics and feasibility. J Am Med Inform Assoc 2015; 22: 29-34.

23. Grünerbl A, Muaremi A, Osmani V, Bahle G, Ohler S, Tröster G, et al. Smartphone-based recognition of states and state changes in bipolar disorder patients. IEEE J Biomed Health Inform 2015; 19: 140-148.

24. Bakker D, Kazantzis N, Rickwood D, Rickard N. Mental Health Smartphone Apps: Review and Evidence-Based Recommendations for Future Developments. JMIR Ment Health 2016; 3: e7. 
25. Callan JA, Wright J, Siegle GJ, Howland RH, Kepler BB. Use of Computer and Mobile Technologies in the Treatment of Depression. Arch Psychiatr Nurs 2016; 31: 311-318.

26. Coulon SM, Monroe CM, West DS. A Systematic, Multi-domain Review of Mobile Smartphone Apps for Evidence-Based Stress Management. Am J Prev Med 2016; 51: 95-105.

27. Kreuze E, Jenkins C, Gregoski M, York J, Mueller M, Lamis DA, Ruggiero KJ. Technology-enhanced suicide prevention interventions: A systematic review of the current state of the science. J Telemed Telecare 2016; 23: 1-13.

28. Meredith SE, Alessi SM, Petry NM. Smartphone applications to reduce alcohol consumption and help patients with alcohol use disorder: A state-of-the-art review. Adv Health Care Technol 2016; 1: 47-54.

29. Li X, Dunn J, Salins D, Zhou G, Zhou W, Schüssler-Fiorenza Rose SM, et al. Digital Health: Tracking Physiomes and Activity Using Wearable Biosensors Reveals Useful Health-Related Information. PLoS Biol 2017; 15: e2001402.

30. Eaton L, Walsh C, Magnuson T, Schweitzer M, Lidor A, Nguyen H, et al. On-line bariatric surgery information session as effective as in-person information session. Surg Obes Relat Dis 2012; 8: 225-229.

31. Heikkinen K, Leino-Kilpi H, Vahlberg T, Salanter S. Ambulatory orthopaedic surgery patients' symptoms with two different patient education method. International Journal of Orthopaedic \& Trauma Nursing 2012; 16: 13-20.

32. Cook DJ, Manning DM, Holland DE, Prinsen SK, Rudzik SD, Roger VL. Patient engagement and reported outcomes in surgical recovery: effectiveness of an e-health platform. J Am Coll Surg 2013; 217: 648-655.

33. Bouwsma EV, Vonk NA, Szlavik Z, Brolmann HA, Emanuel MH, Lips JP, et al. Process evaluation of a multidisciplinary care program for patients undergoing gynaecological surgery. J Occup Rehabil 2014; 24: 425-438.

34. Barello S, Triberti S, Graffigna G, Libreri C, Serino S, Hibbard J, et al. eHealth for Patient Engagement: A Systematic Review. Front Psychol 2015; 6.

35. World Health Organization. WHO e-Health Resolution 2005.

36. Akter S, Ray P. mHealth - an ultimate platform to serve the unserved. Yearb Med Inform 2010: 75-81.

37. Eysenbach G. Consort-ehealth: Improving and Standardizing evaluation reports of web-based and mobile health interventions. J Med 2011; 13: e126.

38. Bisgaard T, Stockel M, Klarskov B, Kehlet H, Rosenberg J. Prospective analysis of convalescence and early pain after uncomplicated laparoscopic fundoplication. Br J Surg 2004; 91: 1473-1478.

39. Tran TT, Kaneva P, Mayo NE, Fried GM, Feldman LS. Short-stay surgery: what really happens after discharge? Surgery 2014; 156: 20-27.

40. Callesen T, Klarskov B, Bech K, Kehlet H. Short convalescence after inguinal herniorrhaphy with standardised recommendations: duration and reasons for delayed return to work. Eur J Surg 1999; 165: 236-241.

41. Vonk NA, Anema JR, Louwerse MD, Heymans MW, van Brolmann HAM, et al. Prediction of time to return to work after gynaecological surgery: a prospective cohort study in the Netherlands. Gynaecological Surgery 2014; 121: 487-497.

42. Brandt CJ, Søgaard GI, Clemensen J, Søndergaard J, Nielsen JB. Determinants of Successful eHealth Coaching for Consumer Lifestyle Changes: Qualitative Interview Study Among Health Care Professionals. Journal of Medical Internet Research 2018; 20: 76-85.

43. Wichers M. The dynamic nature of depression: A new micro-level perspective of mental disorder that meets current challenges. Psychol Med 2014; 44: 1349-1360.

44. Van Borkulo C, Boschloo L, Borsboom D, Penninx BWJH, Waldorp LJ, Schoevers RA. Association of Symptom Network Structure With the Course of Depression. JAMA Psychiatry 2015; 72: 1219.

45. Cramer AOJ, van Borkulo CD, Giltay EJ, van der Maas HLJ, Kendler KS, Scheffer M, Borsboom D. Major depression as a complex dynamic system. PLoS One 2016; 11: e0167490.

46. Nielsen KD, Langstrup H. Tactics of material participation: How patients shape their engagement through e-health. Social Studies of Science 2018; 48: 259-282.

47. Naslund JA, Aschbrenner KA, Barre LK, Bartels SJ. Feasibility of Popular m-Health Technologies for Activity Tracking Among Individuals with Serious Mental Illness. Telemedicine \& e-Health 2015; 21: 213-216.

48. Sander A, Constantinidou F. The interdisciplinary team. J Head Trauma Rehabil 2008; 23: 271-272.

49. Rotondi AJ, Eack SM, Hanusa BH, Spring MB, Haas GL. Critical Design Elements of E-Health Applications for Users With Severe Mental Illness: Singular Focus, Simple Architecture, Prominent Contents, Explicit Navigation, and Inclusive Hyperlinks. Schizophrenia Bulletin 2015; 41: 440-448.

50. Garcia-Palacios A, Herrero R, Vizcaíno Y, Belmonte MA, Castilla D, Molinari G, et al. Integrating virtual reality with activity management for the treatment of fibromyalgia: Acceptability and preliminary efficacy. Clin J Pain 2015; 31: 564-572.

51. Merry SN, Stasiak K, Shepherd M, Frampton C, Fleming T, Lucassen MFG. The effectiveness of SPARX, a computerised self help intervention for adolescents seeking help for depression: Randomised controlled non-inferiority trial. Br Med J 2012; 344: e2598.

52. Lin CF, Hung SI, Chang KT. OFDM-based transport architecture for seamless mobile telemedicine. Proceedings of the Global Mobile Congress; October 2009; Shanghai, China.

53. Nasser MW, Wani NA, Ahirwar DK, Powell CA, Ravi J, Elbaz M, et al. RAGE mediates S100A7-induced breast cancer growth and metastasis by modulating the tumor microenvironment. Cancer Res 2015; 75: 974-985.

54. Orengo-Aguayo RE, Hanson RF, Moreland AD, Jobe-Shields L, Adams ZW. Enhancing the Delivery of an Empirically-Supported Trauma-Focused Treatment for Adolescents: Providers' Views of the Role of Technology and Web-Based Resources. Administration \& Policy in Mental Health \& Mental Health Services Research 2018; 45: 575-586. 
55. Wicks P, Massagli M, Frost J, Brownstein C, Okun S, Vaughan T, et al. Sharing health data for better outcomes on PatientsLikeMe. J Med Internet Res 2010; 12: e19.

56. Berger M, Wagner TH, Baker C. Internet use and stigmatized illness. Soc Sci Med 2005; 61: 1821-1827.

57. Tomlinson M, Rotheram-Borus MJ, Swartz L, Tsai AC. Scaling up mHealth: where is the evidence? PLoS Med 2013; 10: e1001382.

58. Ben-Zeev D, Kaiser SM, Brenner CJ, Begale M, Duffecy J, Mohr DC. Development and Usability Testing of FOCUS: A Smartphone System for Self-Management of Schizophrenia. Psychiatr Rehabil J 2013; 36: 289-296.

59. Depp CA, Mausbach B, Granholm E, Cardenas V, Ben-Zeev D, Patterson TL, et al. Mobile interventions for severe mental illness: design and preliminary data from three approaches. J Nerv Ment Dis 2010; 198: 715-721.

60. Granholm E, Loh C, Swendsen J. Feasibility and validity of computerized ecological momentary assessment in schizophrenia. Schizophr Bull 2008; 34: 507-514.

61. Anthes E. Mental health: There's an app for that. Nature 2016; 532: 20-23.

62. Price M, Yuen EK, Goetter EM, Herbert JD, Forman EM, Acierno R, Ruggiero KJ. mHealth: A mechanism to deliver more accessible, more effective mental health care. Clinical Psychology\& Psychotherapy 2014; 21: 427-436. 